\title{
Covid-19'un Nadir Bir Komplikasyonu Olan Pnömomediastinum
}

\author{
Pneumomediastinum, A Rare Complication of Covid-19 \\ ${ }^{1}$ Canatan TAŞDEMIR, ${ }^{1}$ Yusuf AYDEMIR, ${ }^{1}$ Hasan DÜZENLİ \\ ${ }^{1}$ Sakarya Eğitim ve Araştırma Hastanesi, Gögüs Hastalıkları Kliniği, Sakarya, Türkiye \\ Canatan Taşdemir: https://orcid.org/0000-0003-1856- 9660 \\ Yusuf Aydemir: https://orcid.org/0000-0003-2479-2949 \\ Hasan Düzenli: https://orcid.org/0000-0003-3850-2367
}

\begin{abstract}
ÖZ
Yeni Koronavirüs Hastalığı'nın (COVID-19) çok çeşitli komplikasyonları olmakla birlikte, bunlardan en az görülenlerden biri de pnömomediastinumdur. Mediastinumda serbest hava bulunması olarak tanımlanan pnömomediastinumda, klinik olarak nefes darlığı, göğüs ağrıs1 ve cilt altı amfizemi izlenir. Biz burada hiçbir risk faktörü olmadığı halde COVID-19 ile enfekte bir hastada gelişen spontan pnömomediastinum vakasını sunuyoruz.

Anahtar Kelimeler: Cilt altı amfizemi, corona virüs, pnömomediastinum
\end{abstract}

\section{ABSTRACT}

Although the new coronavirus disease (COVID-19) has a wide variety of complications, one of the least common of these is pneumomediastinum. In pneumomediastinum, which is defined as the presence of free air in the mediastinum, clinically dyspnea, chest pain and subcutaneous emphysema are observed. Here, we present a case of spontaneous pneumomediastinum in a patient infected with COVID-19 without any risk factors.

Keywords: Corona virus, pneumomediastinum, subcutaneous emphysema

\author{
Sorumlu Yazar / Corresponding Author: \\ Canatan Taşdemir \\ Sakarya Eğitim ve Araştırma Hastanesi Göğüs Hastalıkları Kliniği, \\ Sakarya \\ Tel: 05324832280 \\ E-mail: canatan64@hotmail.com
}

Yayın Bilgisi / Article Info:

Gönderi Tarihi/ Received: 27/07/2021

Kabul Tarihi/ Accepted: 08/02/2022

Online Yayın Tarihi/ Published: 01/03/2022

Atıf/ Cited: Taşdemir C ve ark. Covid-19'un Nadir Bir Komplikasyonu Olan Pnömomediastinum. Online Türk Sağlık Bilimleri Dergisi, 2022;7(1):151-155. doi: 10.26453/otjhs.974975

\section{GİRIŞ}

Yeni koronavirüs hastalı̆̆ akut solunum yolu sendromu koronavirüsü 2 (SARS -CoV-2) adı verilen yeni bir virüsün neden olduğu hastalıktır. COVID-19'un en yaygın semptomları; ateş, kuru öksürük, tat ve koku kaybı, burun tıkanıklığ1, boğaz ağrısı, baş ağrısı, kas veya eklem ağrıs1 ve yorgunluktur. ${ }^{1}$ Hastaların $\% 80$ 'i hastanede tedaviye ihtiyaç duymadan iyileşir, yaklaşık \%15'i ciddi bir şekilde hastalanır ve hastane yatışı gerektirir, \%5 kadarı ise yoğun bakıma ihtiyaç duyar. Ölüme yol açan komplikasyonlar arasında, ağır akciğer tutulumuna bağlı solunum yetmezliği, tromboembolizm ve çoklu organ yetmezliği yer alır. 60 yaş üstü kişiler ve yüksek tansiyon, kalp ve akciğer sorunları, diyabet, obezite, kanser gibi altta yatan tıbbi sorunları olanların, ciddi hastalığa yakalanma riski daha yüksektir. ${ }^{1}$ Bununla birlikte, hangi yaşta olursa olsun herkes COVID-19'a yakalanıp ciddi bir şekilde hastalanabilir.

Pnömomediastinum, mediasten de serbest hava bulunmasıdır. ${ }^{2}$ Pnömomediastinumun etiyolojisinde birçok faktör rol oynamakla birlikte oluşum tipine göre primer ve sekonder olmak üzere iki gruba ayr1lır. Pnömomediastinum genellikle solunum veya sindirim sistemi organ perforasyonuna bağlıdır. Primer spontan mediastinum ise periferik alveol rüptürünün sebep olduğu nadir görülen benign bir hastaliktır. ${ }^{2}$

Pnömomediastinumun tanısında, nefes darlığı, göğüs ağrısı ve cilt altı amfizem semptomlarının üçünün olması önemlidir. ${ }^{3}$ En sık bulgusu cilt altı amfizemi 
iken, tipik bulgusu ise göğüs ön kısmında oskültasyon anında kalp tepe atımıyla eş zamanlı olarak duyulan çıtırtı sesidir.,

\section{OLGU SUNUMU}

Etik Komite Onayı: Çalışmamız olgu sunumu olduğu için etik kurul onayı gerekmemektedir. Hastaya bilgilendirilmiş gönüllü olur/onam formu imzalatılmiştır.

40 yaşında, daha önceden hiçbir hastalığı olmayan erkek hasta, 3 gündür başlayan öksürük, halsizlik, ateş ve son 1 gündür başlayan nefes darlığı şikâyetiyle müracaat etti. Hastanın ateşi $36^{\circ} \mathrm{C}$, Nabzı 99/ $\mathrm{dk}$, solunum say1s1 26/dk, tansiyon arteriyeli 110/70 $\mathrm{mmHg}$, oksijen saturasyonu \%88 (oda havasında)ve \%93 (2lt/dk oksijen alırken) olarak ölçüldü.

Fizik muayenesinde; genel durumu orta, şuur açık koopere ve oryente, dispneik ve takipneik görünümdeydi. Dinlemekle solunum sesleri kabayd.

Laboratuar incelemelerinde; hemoglobin: $14.1 \mathrm{~g} / \mathrm{dL}$, hematokrit: \%42.6, lökosit: $12700 \mathrm{~K} / \mathrm{uL}$, lenfosit: 634 (\%4.98), C reaktif protein: $114 \mathrm{mg} / \mathrm{L}$, prokalsi- tonin: $0.319 \mathrm{ng} / \mathrm{ml}$, interlökin-6: $15.08 \mathrm{pg} / \mathrm{ml}$, laktat dehidrogenaz: $694 \mathrm{U} / \mathrm{L}$, ferritin: $2190 \mu \mathrm{g} / \mathrm{L}$, Ddimer: 502 ugFEU/L olarak ölçüldü.

Hastanın çekilen toraks bilgisayarlı tomografisinde (BT), bilateral parankimal yamasal buzlu cam alanları mevcuttu (Şekil 1). Hastada viral pnömoni düşünülerek COVID-19 PCR testi istendi ve kliniğimize yatırılarak tedavisi başlandi.

Hastada tedavinin dördüncü gününde aniden gögüs ağrısı ve nefes darlığında artma şikâyeti başladı. Fizik muayenesinde daha önceden olmayan, boyun ve göğüs ön kısmında palpasyonla krepitasyon tespit edildi. Dinlemekle göğüs ön kısmında, kalp tepe atımıyla eş zamanlı çıtırtı sesi vardı. Çekilen akciğer grafisinde, boyunda ve supraklaviküler bölgede cilt altı amfizemine bağlı hava gölgeleri gözlendi (Şekil 2).

Hastanın yeni toraks BT görüntüleri alındı. Gögüs duvarını çevreleyen yaygın gaz koleksiyonları (cilt altı amfizemi) ve pnömomediastinum izlendi (Şekil $3)$.

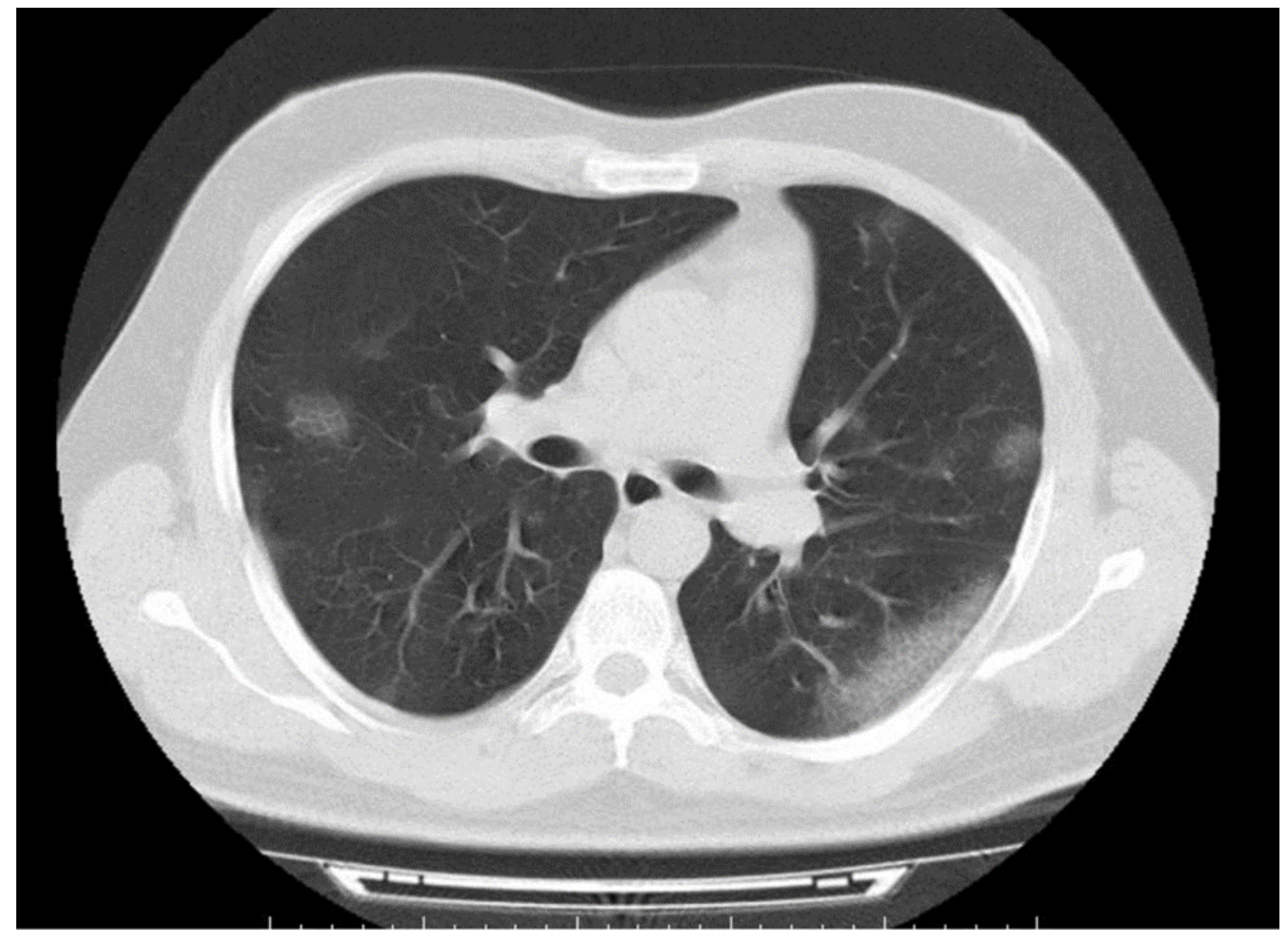

Şekil 1. Toraks BT'de bilateral yamasal buzlu cam alanları. 
COVID-19 PCR testi pozitif sonuçlanan hastaya, Favipravir tedavisi 5 gün, Enoksaparin Sodyum 2x4000 IU 10 gün, Deksametazon 16 mg 10 gün, Famotidin 10 gün, Moxifloxasin İV 5 gün, Anakinra 1.gün 4x100 mg, 2.gün 3x100 mg, 3. gün 2x100 mg ve izleyen 4 gün 1x100 mg olacak şekilde toplam 7 gün süreyle verildi. Ayrıca hastaya rezervuarlı mas- ke ile oksijen tedavisi uygulandı. Yüksek akımlı oksijen ihtiyacı olmadı. Hastanın günlük PA akciğer grafisi ile takibi yapıld1, tedavinin onuncu gününde cilt altı amfizemine bağlı krepitasyonlar tamamen kayboldu. Çekilen akciğer grafisinde cilt altı amfizemine bağlı hava imajları kaybolmuştu (Şekil 4). Has-

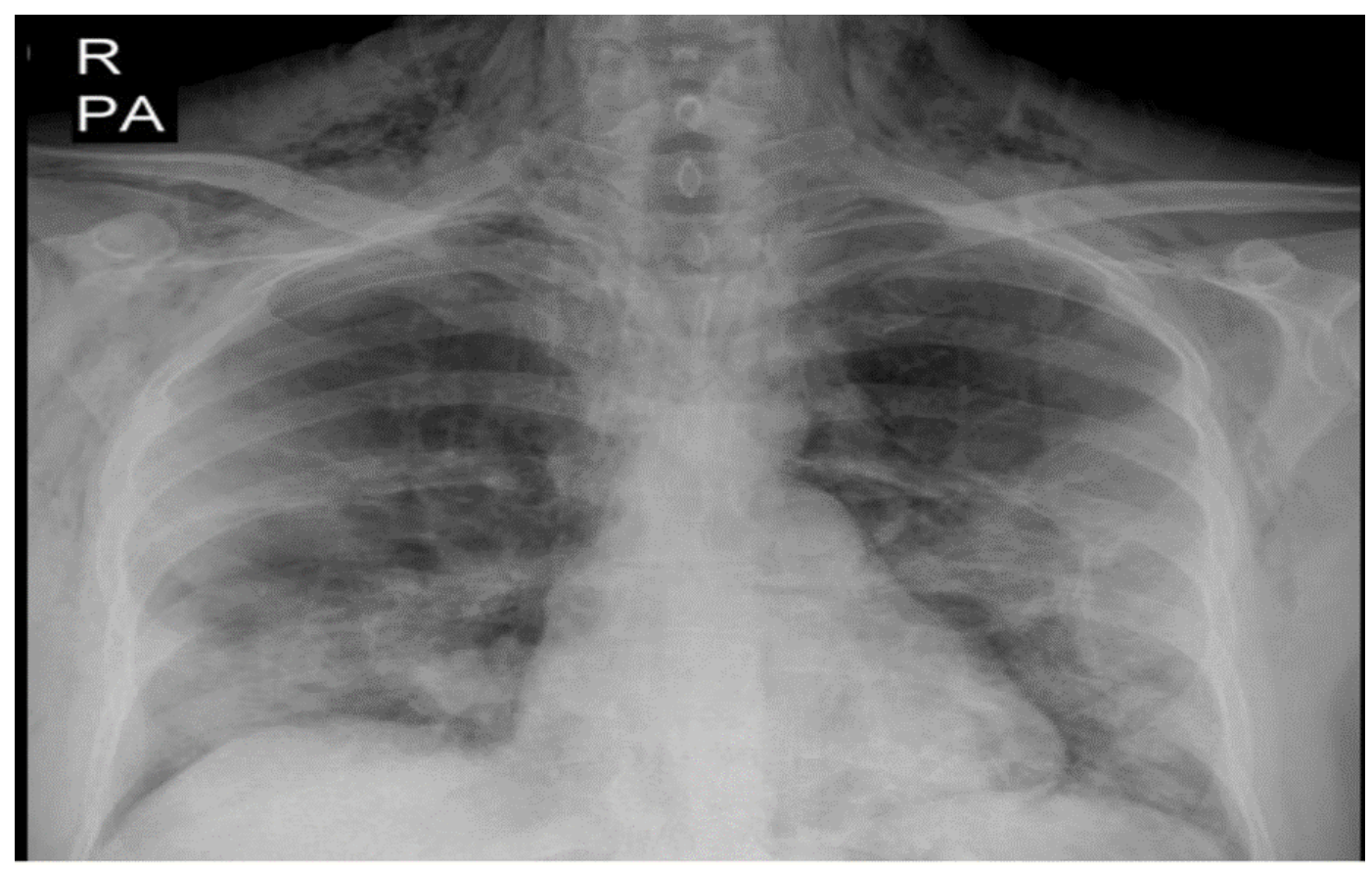

Şekil 2. Akciğer grafisinde boyun ve supraklaviküler bölgelerde cilt altı amfizemi ile uyumlu hava dansiteleri.

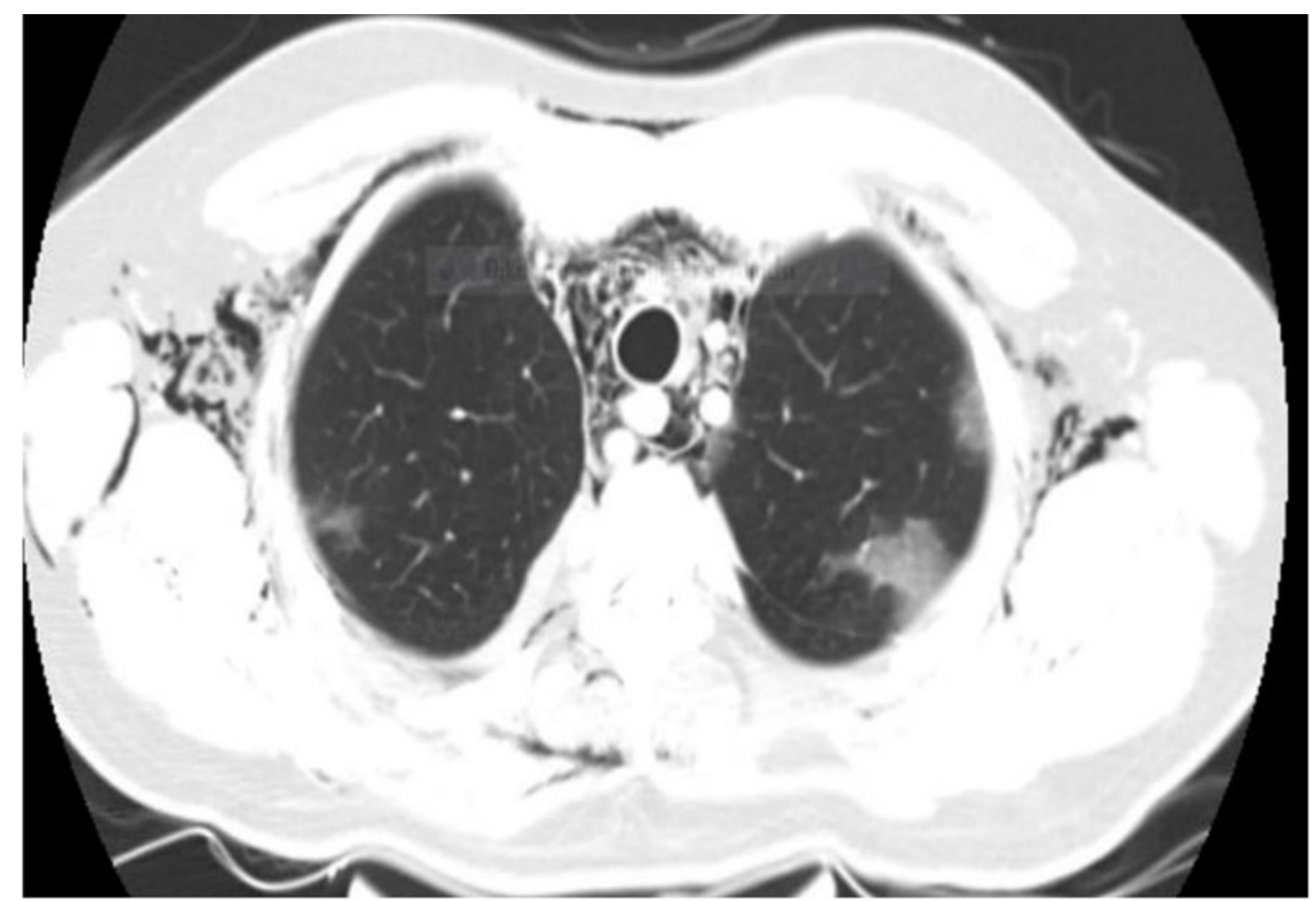

Şekil 3. Toraks BT'de mediastinal ve cilt altı hava gölgeleri. 
tanın saturasyonu 2 lt/dk oksijen alırken $\% 95$, oksijensiz ve hafif efor sonras 1 ise $\% 92$ idi.

Genel durumu düzelen hasta oksijensiz olarak taburcu edildi.

\section{TARTIŞMA VE SONUC}

COVID-19 'un çeşitli komplikasyonları arasında nadir de olsa pnömotoraks ve pnömomediastinum yer almaktadır. COVID-19 da spontan pnömomediastinumun bildiren çok az sayıda rapor vardır. Üçpınar ve ark. başvurusunda spontan pneumotoraks ve pneumomediastinumun birlikte olduğu bir COVID19 vakası bildirmişlerdir. ${ }^{6}$ Shan ve ark. başvurusunda cilt altı amfizemi, pnömotoraks ve pnömomediastinumun birlikte olduğu bir COVID-19 vakası bildirmişlerdir. ${ }^{7}$ Yapılan çok merkezli retrospektif bir vaka serisinde 16 merkezden 71 COVID-19 isbatlanmış hastanın, 54'ünde pnömotoraks, 6'sında pnömotoraks ve pnömomediastinum birlikteliği, 11 'inde pnömomediastinum bildirilmiştir. ${ }^{8}$ Pnömotoraks ve pnömomediastinum, spontan olarak COVID-19 hastalarında nadiren görülebilmekle birlikte, daha sık olarak invaziv pozitif basınçlı ventilasyonun bir komplikasyonu olarak görülebilmektedir. ${ }^{9}$ Pnömomediastinum tanısında radyolojik inceleme önemli yere sahiptir. Genellikle PA Akciğer grafisi ve Toraks BT'de cilt altı amfizemi ayırt edilebilir. $\mathrm{Bu}$ nedenle ani klinik kötüleşme olan hastalarda kontrol akciğer grafisi çekilmelidir.
Pnömomediastinumun oluşum mekanizması henüz tam olarak bilinmemektedir. Olası bir açıklama, şiddetli pnömoninin yaygın alveoler hasara ve yırtılmaya neden olarak, mediastinal boşluğa ve subkutan amfizeme ilerleyebilen interstisyel amfizeme yol açıyor olmasıdır. Ciddi solunum ve dolaşım bozukluğuna yol açma potansiyeline sahip bir durum olsa da, genellikle kendi kendini sınırlayan bir hastalıktır. Buna rağmen, özellikle mekanik ventilatör altındaki hastalarda tedavi yönetimine değişiklikler (volütravmayı önlemek için yüksek ekspiratuar basınçlardan kaçınmak gibi) gerektirir. İlaveten orta ağır akciğer tutulumuna bağlı sınırlı solunum fonksiyonları olan hastalarda ölümcül bir komplikasyon olabilmektedir. $^{10}$

Sonuç olarak pnömomediastinum COVID-19'un bir komplikasyonu olarak görülebilir. Ani olarak saturasyon düşüklüğünün, nefes darlığının, göğüs ağrısının başladığı COVID-19 hastalarında, cilt altı amfizemi varlığına da bakılmalı, palpasyonla krepitasyon olması pnömomediastinumu düşündürmelidir. Böyle hastalarda invaziv basınçlı ventilasyon öncesi toraks görüntülemesi tekrarlanarak tanı doğrulanmalıdır.

Etik Komite Onayı: Çalışmamız olgu sunumu olduğu için etik kurul onayı gerekmemektedir. Hastaya bilgilendirilmiş gönüllü olur/onam formu imzalatılmıştır.

Çıkar Çatışması: Yazarlar çıkar çatışması bildirme-

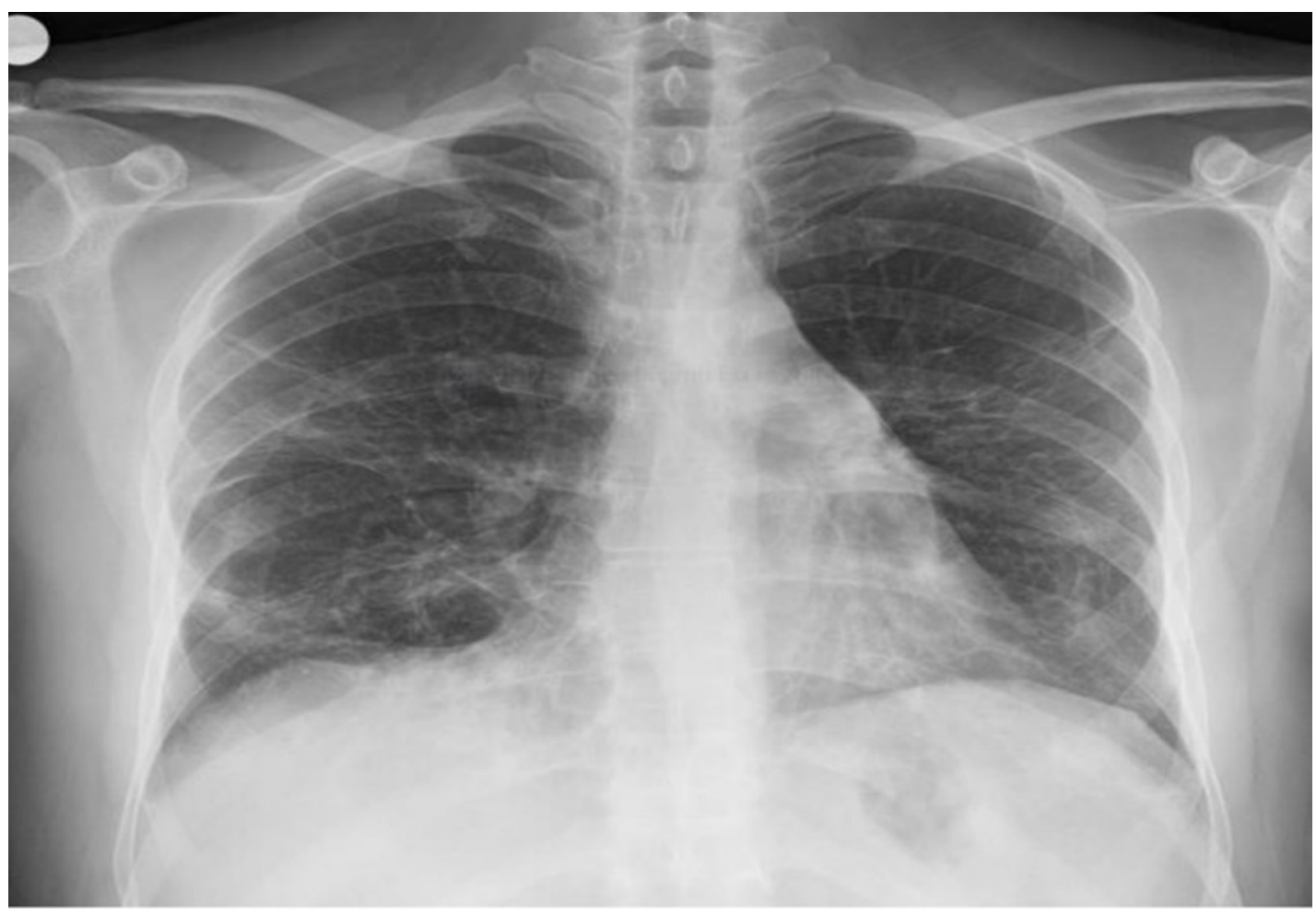

Şekil 4. Tedavi sonrası çekilen Akciğer grafisi. 
mişlerdir.

Yazar Katklları: Vaka izlemi-CT, YA, HD; Veri toplanması ve işlenmesi-CT; Yazıyı yazan-CT.

Hakem Değerlendirmesi: Dış bağımsız.

Finansal Destek: Yok

\section{KAYNAKLAR}

1. World Health Organization (WHO). Coronavirus disease (COVID-19). https://www.who.int/ emergencies/diseases/novel-coronavirus-2019/ question-and-answers-hub/q-a-detail/ coronavirus-disease-covid-19. Erişim tarihi 06 Şubat 2022.

2. Wintermark M, Schnyder P. The Macklin effect: A frequent etiology for pnömomediastinum in severe blunt chest trauma. Chest. 2001;120(2);543-547. doi:10.1378/ Chest.120.2.543

3. Ralp-Edwards AC, Pearson FG. Atypical presentation of spontaneous pneumomediastinum. Ann Thorac Surg. 1994;58(6):1758-1760. doi:10.1016/0003-4975(96)9183-7

4. Adadıŏlu İ, Yavuz Y, Solak O, Yürümez Y, Eşme H. Primer spontan pnömomediastinum: Olgu Sunumu. AKATOS. 2010;1(1):37-40.

5. Damor DT, Dayan PS. Medical causes of pneumomediastinum in children. Clin Pediatr. 2001;40(2):89-91.

doi:10.1177/000992280104000204

6. Üçpınar BA, Şahin C, Yanc Y. Spontaneous pneumothorax and subcutaneous emphysema in COVID-19 patient: Case report. J Infect Public Health. 2020;13(6):887-889. doi: 10.1016/ j.jiph.2020.05.012

7. Shan S, Guangming I, Wei L, Xuedong Y. Spontaneous pneumomediastinum, pneumotorax and subcutaneous emphysema in COVID19: Case report and literature review. Rev Inst Med Trop Sao Paulo. 2020;62:e76. doi:10:1590/51678-9946202062076

8. Martinelli $\mathrm{AW}$, Ingle $\mathrm{T}$, Newman $\mathrm{J}$, et al. COVID-19 and pneumotorax: A multicentre retrospective case series. Eur Respir J. 2020;56 (5):2002697. doi:10.1183/13993003.2020

9. Zhou C, Gao C, Xie Y, Xu M. COVID-19 with spontaneous pneumomediastinum. The Lancet Infectious Diseases. 2020;20(4):510. doi:10.1016/51473-3099(20)30156-0

10. Loffi M, Regazzoni V, Sergio P, et al. Spontaneous pneumomediastinum in COVID-19 pneumonia. Monaldi Arch Chest Dis. 2020;90(4). doi:10.4081/monaldi.2020.1399 